
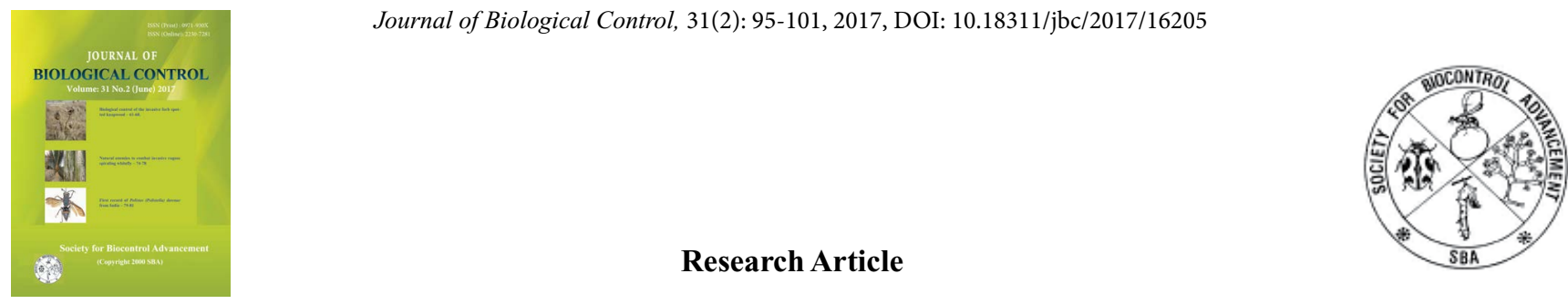

\title{
Compatibility of Steinernema carpocapsae and Heterorhabditis indica with insecticides registered against Helicoverpa armigera (Lepidoptera: Noctuidae)
}

\author{
DEVINDRAPPA ${ }^{1}$, JAGADEESH PATIL ${ }^{2 *}$, MANJUNATHA T. GOWDA ${ }^{3}$, and R. VIJAYAKUMAR ${ }^{2}$ \\ ${ }^{1}$ Indian Institute of Pulses Research, Kanpur-208024, Uttar Pradesh, India \\ ${ }^{2}$ National Bureau of Agricultural Insect Resources, Bengaluru - 560024, Karnataka, India \\ ${ }^{3}$ Indian Institute of Vegetable Research, Varanasi - 221305, Uttar Pradesh, India \\ *Corresponding author E-mail: patiljaggi@gmail.com
}

\begin{abstract}
The gram pod borer, Helicoverpa armigera (Lepidoptera: Noctuidae) is considered as a key pest of pigeonpea and is also a major polyphagous pest of several agricultural and horticultural crops in India. Combining chemical insecticides with Entomopathogenic Nematodes (EPNs) could be an effective alternative to reduce the use of harmful chemicals. Experiments were conducted to determine the compatibility of Steinernema carpocapsae and Heterorhabditis indica with registered insecticides used for H. armigera control in pigeon pea, under laboratory conditions. Compatibility of the insecticides with EPNs was evaluated by observing infective juveniles (IJs) survival and virulence of Galleria mellonella at 24 and $48 \mathrm{~h}$ after dipping in insecticide solutions. It was observed that, insecticides showed moderate effect on IJs survival. IJs were able to infect $G$. mellonella larvae after exposure to these chemicals, but their progeny production was significantly $(P<0.05)$ reduced. Both nematode species showed differential sensitivity to the tested insecticides, with $H$. indica exhibiting better tolerance than $S$. carpocapsae. The studies revealed that the chemicals showed a strong sub lethal effect on the nematode reproductive potential, limiting seriously their possible recycling in the field.
\end{abstract}

KEY WORDS: Compatibility, Galleria mellonella, Helicoverpa armigera, Heterorhabditis indica, Steinernema carpocapsae

(Article chronicle: Received: 02.06.2017; Revised 21.06.2017; Accepted: 29.06.2017

\section{INTRODUCTION}

Helicoverpa armigera (Hubner) is an important polyphagous pest causing severe damage to several agricultural and horticultural crops (Reed and Pawar, 1982; Zalucki et al., 1986; Fitt, 1989; Gowda, 2005). This pest feeds nearly 182 species of plants spanning 47 families and among them 56 plant species are severely damaged (Pawar et al., 1986). An estimated US\$ 2 billion is annually lost due to this pest (Sharma, 2005), of which US\$ 550 million accounts for loss in chickpea and Pigeonpea (ICRISAT, 1992).

Over use of chemical insecticides are common when $H$. armigera incidence is severe. Hence, with increased awareness among farmers to adopt safer control measures there is increasing emphasis on integrated pest management (IPM) where biological control agents can be deployed for management of $H$. armigera. Entomopathogenic nematodes (EPNs) belonging to the families of Steinernematidae and Heterorhabditidae are considered as suitable biocontrol agents, because of their ability to infect, kill and reproduce inside the some species. This has been well established with $H$. armigera and $H$. zea both in laboratory and field condi- tions (Glazer and Navon., 1990; Naser et al., 2012; Hussain et al., 2014; Kallia et al., 2014; Cabanillas et al., 1994).

The integration of EPNs in IPM technique for combating $H$. armigera, will reduce the dependence on many conventional insecticides, thereby preventing harmful effects on human and soil (Dent, 2000). However, before an IPM technique for the control of this pest can be brought out, it is important that the compatibility of the nematodes with insecticides registered against this pest needs to be established. Moreover, chemical insecticide developing industries often do not test product toxicity to entomopathogens, only safety for predators and parasitoids is established (Alves et al., 1998). Hence, research is needed to know whether the insecticides are having any deleterious effect on EPNs before combining them with insecticides. The present investigation was carried out to evaluate compatibility of $S$. carpocapsae and $H$. indica with chemical insecticides registered against $H$. armigera under laboratory conditions, so as to enable the integration of these control methods into effective management strategies. This paper reports the effect of direct exposure to insecticide solutions on the sur- 
vivability, infectivity and reproduction of $S$. carpocapsae and $H$. indica.

\section{MATERIALS AND METHODS}

\section{Insect culture}

Wax moth, Galleria mellonella (L.) (Lepidoptera: Pyralidae), was reared under laboratory conditions at $25 \pm$ $2{ }^{\circ} \mathrm{C}$ on standard artificial diet. The moths collected in plastic jars were fed with honey solutions. They were allowed to lay eggs on a tissue paper lining. The eggs were allowed to hatch in a separate plastic jar covered with muslin cloth. Newly hatched larvae (0-24 h old) were released on artificial diet containing plastic jar covered with muslin cloth. After reaching the last larval instar, healthy larvae were used for the experiment.

\section{Insecticides}

To determine the compatibility of Steinernema carpocapsae Weiser, 1955 (Wouts, Mracek, Gerdin and Bedding, 1982) and Heterorhabditis indica (Poinar, Karunakar and David, 1992) infective juveniles (IJ) with seven com- mercial insecticides registered for Helicoverpa armigera in pigeonpea were evaluated. Details about the insecticides are listed in Table 1 and 2.

\section{Nematode culture}

Steinernema carpocapsae and Heterorhabditis indica obtained from the Department of Insect Systematics, ICAR- National Bureau of Agricultural Insect Resources (NBAIR) Bengaluru, India, were used in this study. Nematodes were propagated in parallel at room temperature on final instar Galleria larvae (Kaya and Stock 1997). IJs emerging from the larvae within 3 days from the first day of emergence were collected. Nematode viability was $100 \%$, unless otherwise stated. New batch of IJs were used in all the experiments.

\section{Effect of insecticides on EPNs survival}

To determine compatibility of EPNs with registered insecticides for $H$. armigera in pigeonpea, a laboratory assay was conducted. Before the assay, seven registered insecticides aliquot suspension was prepared by using, active

Table 1. Characteristics of insecticides registered in India for the management of Helicoverpa armigera in Pigeonpea

\begin{tabular}{|c|c|c|c|c|c|c|}
\hline \multicolumn{2}{|l|}{ Name } & \multirow[t]{2}{*}{ Formulation } & \multirow[t]{2}{*}{ Mode of action ${ }^{\mathrm{a}}$} & \multirow[t]{2}{*}{ Chemical group } & \multirow{2}{*}{$\begin{array}{l}\text { Concentration } \\
\mathrm{Kg} \text { or Liter/ha }{ }^{\mathrm{b}}\end{array}$} & \multirow{2}{*}{$\begin{array}{l}\text { Spray volume } \\
{\text { Liter} / \mathrm{ha}^{\mathrm{c}}}\end{array}$} \\
\hline Technical & Commercial & & & & & \\
\hline Emamectin benzoate & Proclaim $\AA$ & $5 \% \mathrm{SG}$ & Ggcca & Avermectins & 0.220 & $500-750$ \\
\hline Flubendiamide & Fame ${ }^{\circledR}$ & $39.35 \% \mathrm{SC}$ & IRRA & Diamide & 0.1 & 500 \\
\hline Indoxcarb & King Dox ${ }^{\circledR}$ & $14.5 \% \mathrm{SC}$ & SDM & Oxadiazines & $0.35-0.40$ & $500-1000$ \\
\hline Lambdacyhalo-thrin & Ballista Super ${ }^{\circledR}$ & $5 \% \mathrm{EC}$ & SDM & Pyrethroids & $0.40-0.50$ & $400-600$ \\
\hline Profenophos & Attach $\mathbb{R}$ & $50 \% \mathrm{EC}$ & $\mathrm{CI}$ & Organophosphates & $1.5-2.0$ & $500-1000$ \\
\hline $\begin{array}{l}\text { Profenophos }+ \\
\text { Cypermethrin }\end{array}$ & Prolife Super® & $40 \% \mathrm{EC}+4 \% \mathrm{EC}$ & $\begin{array}{l}\text { CI and } \\
\text { SDM }\end{array}$ & $\begin{array}{l}\text { Organophosphates }+ \\
\text { Pyrethroid }\end{array}$ & $1.0-1.5$ & $500-1000$ \\
\hline Monocrotophos & Monoplus ${ }^{\circledR}$ & $36 \% \mathrm{SL}$ & $\mathrm{CI}$ & Organophosphates & 1.25 & $500-1000$ \\
\hline
\end{tabular}

${ }^{a}$ Mode of action, $\mathrm{Ggcca}=\mathrm{GABA}$ gated chloride channels activators, IRRA $=$ Insect Ryanodine

Receptors agonist, $\mathrm{SDM}=$ Sodium channel modulator, $\mathrm{CI}=$ Cholinesterase inhibitor

${ }^{\mathrm{b}}$ Corresponding to terrestrial application.

${ }^{c}$ Corresponding to aerial application.

Table 2. Insecticides registered in India for Helicoverpa armigera in pigeonpea, toxicity classification of insecticides; the effect of the treatments on entomopathogenic nematodes infectivity of Galleria mellonella larvae was classified according Peters and Poullot (2004), based on IOBC guideline

\begin{tabular}{|c|c|c|c|c|c|c|c|c|}
\hline \multirow[t]{3}{*}{ Treatment $^{\mathrm{a}}$} & \multicolumn{4}{|c|}{ Steinernema carpocapsae } & \multicolumn{4}{|c|}{ Heterorhabditis indica } \\
\hline & \multicolumn{2}{|c|}{$24 \mathrm{~h}$} & \multicolumn{2}{|l|}{$48 \mathrm{~h}$} & \multicolumn{2}{|c|}{$24 \mathrm{~h}$} & \multicolumn{2}{|l|}{$48 \mathrm{~h}$} \\
\hline & $\mathrm{E} \%{ }^{\mathrm{b}}$ & $\mathrm{C}^{\mathrm{c}}$ & $\mathrm{E} \%$ & $\mathrm{C}$ & $\mathrm{E} \%$ & $\mathrm{C}$ & $\mathrm{E} \%$ & $\mathrm{C}$ \\
\hline Proclaim ${ }^{\circledR}$ & 100.0 & 4 & 100 & 4 & 100.0 & 100.0 & 100.0 & 4 \\
\hline Fame ${ }^{\circledR}$ & 0.0 & 1 & 0.0 & 1 & 0.0 & 1 & 0.0 & 1 \\
\hline King Dox ${ }^{\circledR}$ & 0.0 & 1 & 0.0 & 1 & 0.0 & 1 & 0.0 & 1 \\
\hline Ballista Super ${ }^{\circledR}$ & 6.7 & 1 & 33.4 & 2 & 20.0 & 1 & 26.7 & 1 \\
\hline $\operatorname{Attach} \AA$ & 46.7 & 2 & 60.0 & 2 & 13.4 & 1 & 60.0 & 2 \\
\hline Prolife Super ${ }^{\circledR}$ & 46.7 & 2 & 66.7 & 2 & 53.4 & 2 & 66.7 & 2 \\
\hline Monoplus ${ }^{\circledR}$ & 33.4 & 2 & 40.0 & 2 & 40.0 & 2 & 46.7 & 2 \\
\hline
\end{tabular}

${ }^{a}$ a.i./ha recommended for aerial application.

b Treatment effects: E\% $=100$ - $(100$ - corrected mortality $) \times(100 \times$ Red $) . \%$ corrected mortality was null in all treatments and therefore it was not considered in $\mathrm{E} \%$ calculation.

c Toxicity classification of insecticides by IOBC: 1 - non-toxic $(<30 \%), 2$ - slightly toxic (30 to $79 \%), 3$ - moderately toxic $(80 \%$ to $99 \%)$ and $4-$ harmful (>99\%). 
ingredient (a.i.) /ha recommended for field application and their spray volume (Table 1), in which each insecticide a.i. was calculated for $10 \mathrm{ml}$ spray volume. Each calculated insecticide a.i. was dissolved in $9 \mathrm{ml}$ distilled water and mixed with approximately 10000 fresh IJs containing $1 \mathrm{ml}$ distilled water. After preparing each insecticide final suspension, $2 \mathrm{ml}$ of aliquots of each suspension was placed in 24 well plates and $2 \mathrm{ml}$ distilled water were used for the control treatment. Plates were sealed with Para film to avoid evaporation and these plates were incubated at $25 \pm 1^{\circ} \mathrm{C}$ for 24 and $48 \mathrm{~h}$. After exposure, the number of dead and live IJs was counted under a stereomicroscope by taking three $10 \mu \mathrm{l}$ samples for each plate and percentage survival was calculated. Nematode viability was determined by observing motility and they were considered dead if not responding to probing with a fine needle. There were five wells per insecticide, nematode species, exposure time and assay was repeated once.

\section{Effect of insecticide on EPNs virulence}

To study the nematode infectivity, which is the capability to cause nematode death, first IJs were exposed to different insecticides as mentioned above. IJs infectivity and mortality were tested using Galleria as a host. After exposure, multi well plate were filled with $2 \mathrm{ml}$ of distilled water and placed to rest for $30 \mathrm{~min}$ at $25 \pm 1^{\circ} \mathrm{C}$. Supernatant liquid (approximately $2 \mathrm{ml}$ ) was then withdrawn and the rinsing in distilled water, process repeated for four times. After the last rinsing, a volume of $150 \mu$ (approximately $150 \mathrm{IJs}$ ) were retrieved from the bottom of each tube and distributed in petri dish ( $9 \mathrm{~cm}$ diameter) containing filter paper previously wetted with $850 \mu$ l distilled water for each treatment. Each plate received three last instar $G$. mellonella larvae, incubated at $25 \pm 1^{\circ} \mathrm{C}$ till death of the larvae. After death, insect cadaver were transferred to Petri dish (9 $\mathrm{cm}$ diameter) containing dry filter paper and maintained in darkness for $24 \mathrm{~h}$, finally they were dissected in order to verify nematode's presence. There were five replicates per insecticide, nematodes species, Exposure time and the assay was repeated once.

\section{Effect of insecticide on EPNs reproduction}

To assess the nematode reproduction for each nematode species, above mentioned nematodes infectivity method was followed. After death of wax moth larvae, three cadavers were rinsed in sterile distilled water to remove nematodes from their surface body. Then cadavers were incubated at $25 \pm 1^{\circ} \mathrm{C}$ in dark at room temperature for 7 and 10 days for $S$. carpocapsae and $H$. indica respectively. The total number of IJs that emerged from each larva was determined. There were five replicates per insecticide, nematodes species, exposure time and assay was repeated once.

\section{Statistical analysis}

Percentage data were normalized using arcsine transformation and numerical data (progeny production) were square root transformed prior to analysis. Analysis was undertaken on the transformed data and back transformed data only is presented. Insecticides, time and nematode species and their interactive effects on nematode survival, infectivity, and progeny production data were subjected to analysis of variance (ANOVA) using PROC GLM (SAS version 9.3; SAS institute). When ANOVA was significant, comparisons of relevant means were made using the Tukey's significance test values at the $5 \%$ level of significance. The effect of the treatments on EPNs infectivity of Galleria larvae was classified according Peters and Poullot (2004), based on the International Organization for Biological Control (IOBC) guideline and the formula.

\section{RESULTS AND DISCUSSION}

\section{Effect of insecticide on EPNs survival}

Irrespective of the nematode species, Prolife Super ${ }^{\circledR}$ and Attach $^{\circledR}$ were the insecticides that caused the lowest survival $(<50 \%)$ of the two EPNs tested. Survivability of $H$. indica and $S$. carpocapsae IJs was significantly different when exposed to the different insecticides. The survivability of $S$. carpocapsae was lowest in mixture with Monoplus $^{\circledR}(15.8 \%)$, Prolife $\operatorname{Super}^{\circledR}$ (24.3\%) and Attach ${ }^{\circledR}$ (36.7\%) while for $H$. indica was lowest in mixture with Prolife Su$\operatorname{per}^{\circledR}(31.8 \%)$ and $\operatorname{Attach}^{\circledR}(45.5 \%) 48 \mathrm{~h}$ after their exposure to these insecticides. However, $H$. indica survivability was not significantly different between 24 and $48 \mathrm{~h}$ after their exposure to Monoplus ${ }^{\circledR} 52.2 \%$ and $51.2 \%$, respectively. Among the nematode species, irrespective of insecticides, the per cent survival of $H$. indica was significantly $(P<$ 0.05 ) higher compared to the $S$. carpocapsae (Fig. 1). When exposure time of IJs was extended up to $48 \mathrm{~h}$, the survivability of the nematode species were significantly $(P$ $<0.05$ ) reduced. Insecticides and exposure period significantly influenced nematode survival.

\section{Effect of insecticide on EPN infectivity}

Infectivity, that is, capacity of $S$. carpocapsae and $H$. indica to cause $G$. mellonella larval death was statistically $(P<0.05)$ different after being exposed to the insecticides. Independently from nematodes, infectivity was higher after exposure to Fame $^{\circledR}(100 \%)$, King-Dox ${ }^{\circledR}(100 \%)$ and Ballista $\operatorname{Super}^{\circledR}(85.0 \%)$. Infectivity of $S$. carpocapsae was equal to the control in treatments with Fame $^{\circledR}(100 \%)$ and King-Dox ${ }^{\circledR}(100 \%)$, the lowest infectivity registered when exposed to Prolife Super ${ }^{\circledR}$ (33.3\%) for 48 h. Similarly, $H$. indica was highly infective after being exposed to Fame ${ }^{\circledR}$ $(100 \%)$, King-Dox ${ }^{\circledR}(100 \%)$ and Ballista Super $^{\circledR}(73.3 \%)$, 

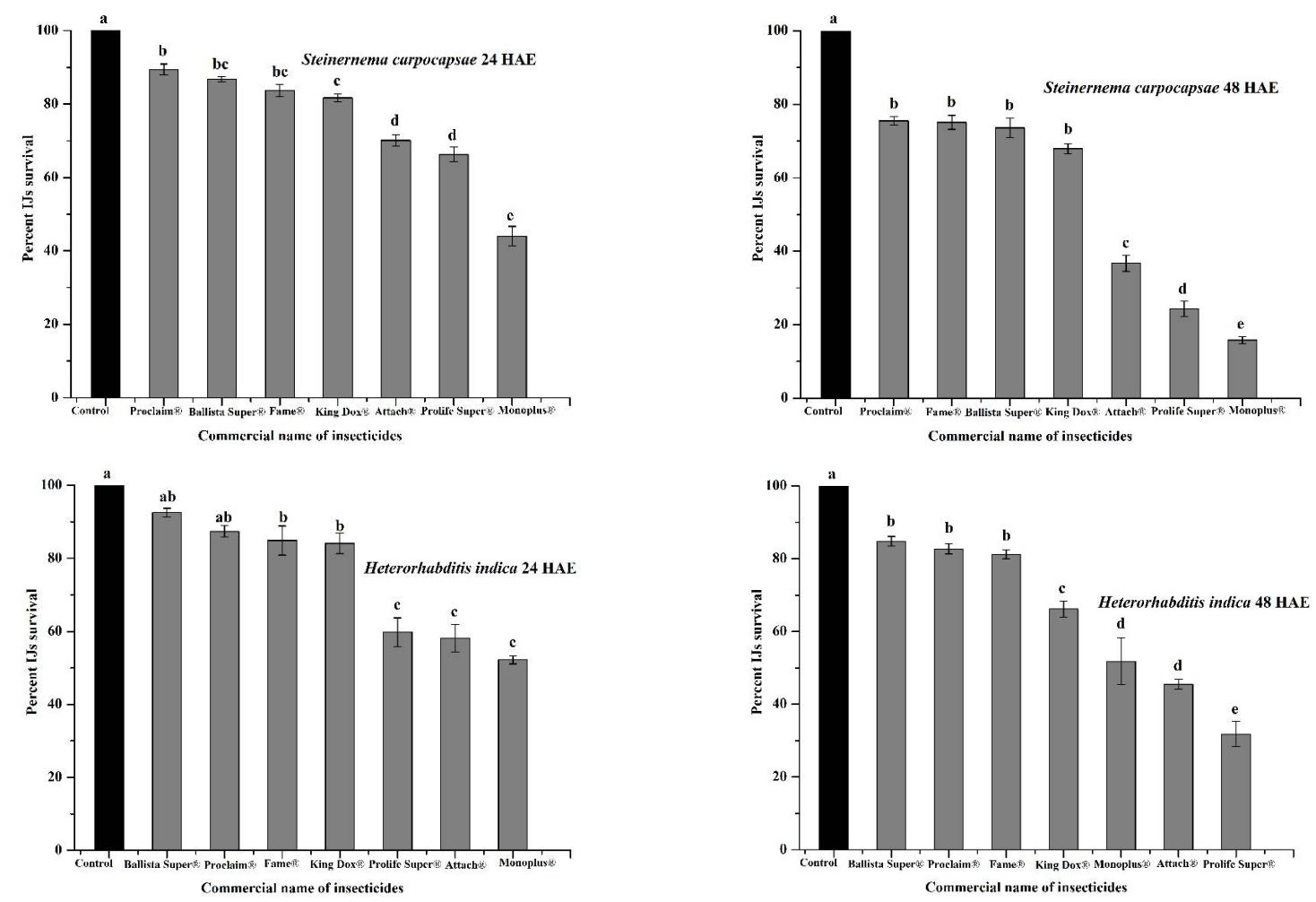

Fig. 1. Percentage survival (Mean \pm SE) of Steinernema carpocapsae and Heterorhabditis indica after 24 and 48 hours after exposure (HAE) to registered insecticides for the management of Helicoverpa armigera. Different letters on the top of error bars indicates statistically different values for different insecticide a.i./ha recommended for aerial application at $(P<0.05)$ using Tukey's test. Error bars indicate standard error $(n=5)$.

Prolife $\operatorname{Super}^{\circledR}(33.3 \%)$ caused the lowest infectivity of this G. mellonella when exposed to Proclaim ${ }^{\circledR}$ (Table 3). nematode. However, both nematodes species failed to infect

Table 3. The infectivity (Mean \pm SE) capacity of Steinernema carpocapsae and Heterorhabditis indica, to Galleria mellonella larvae after 24 and 48 hours exposure in Helicoverpa armigera registered insecticides

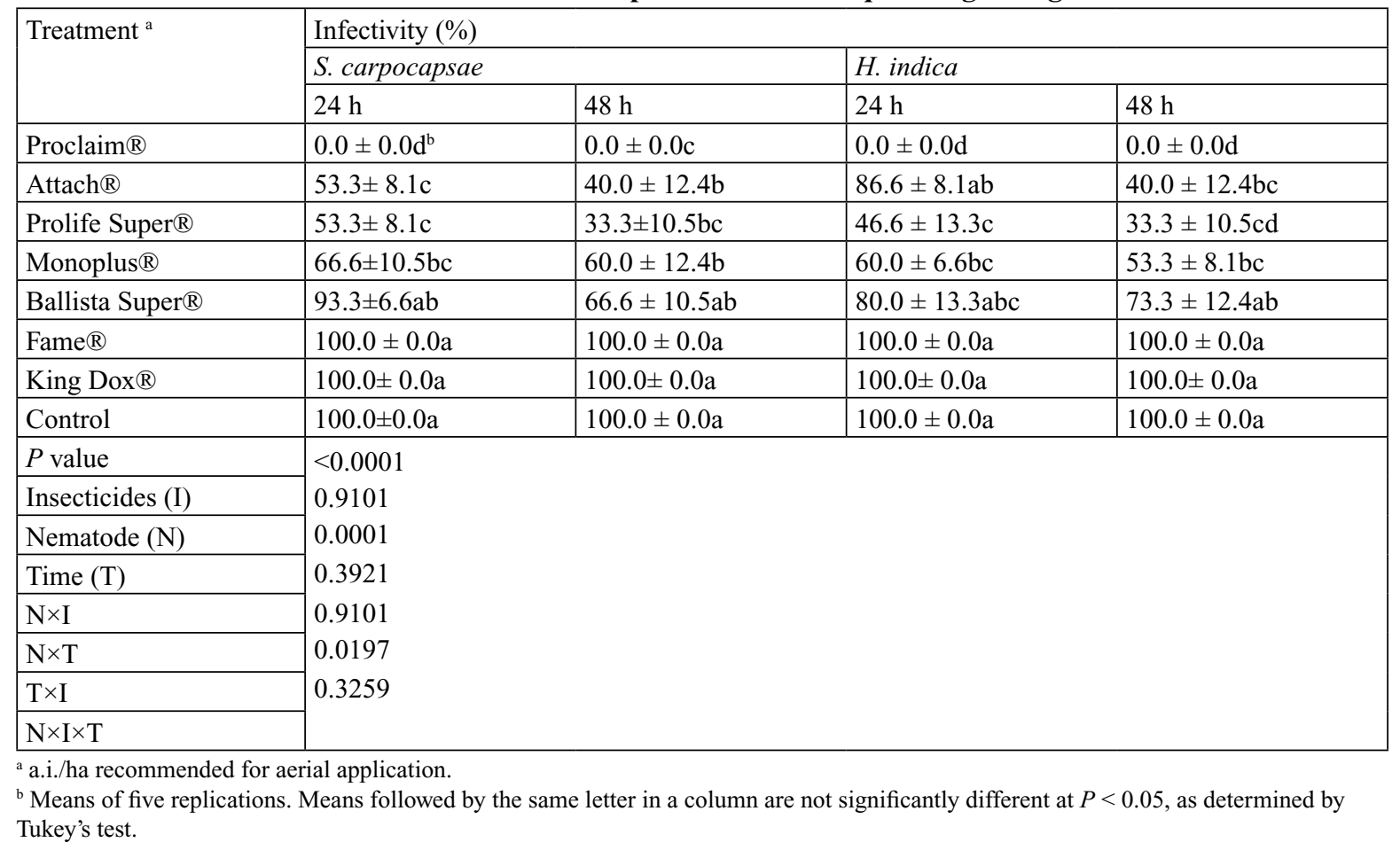




\section{Effect of insecticide on EPN reproduction}

Reproduction of both nematode species was significantly $(P<0.05)$ affected by insecticides and time of exposure. For both nematodes, the number of progeny produced per milligram body weight of Galleria larvae was significantly $(P<0.05)$ reduced when IJs were exposed to insecticides before the inoculation. Reproduction was significantly $(P<0.05)$ reduced in both nematode species, after exposure to all the insecticides when compared to control. Reproduction of $S$. carpocapsae being the lowest, registered when exposed to Prolife Super ${ }^{\circledR}$ (699 IJs/ mg body weight) for $24 \mathrm{~h}$. Similarly, $H$. indica reproduction was not significantly different between Fame ${ }^{\circledR}$, Ballista Super ${ }^{\circledR}$ and King Dox ${ }^{\circledR}$. Monoplus ${ }^{\circledR}$ (516 IJs/ mg body weight) caused the lowest reproduction of this nematode when IJs exposed for $24 \mathrm{~h}$ (Fig. 2).

It has been well established that the combined use of biological control agents like EPN and insecticides are important to IPM programs against many agricultural pests (Koppenhofer and Grewal, 2005). To study the adverse effects of insecticides on natural enemies (Nabil El-Wakeil et $a l ., 2013)$ and especially on EPNs, it's pre-requisite to validate the compatibility of EPNs with insecticides, because it has one of the important agriculture inputs commonly
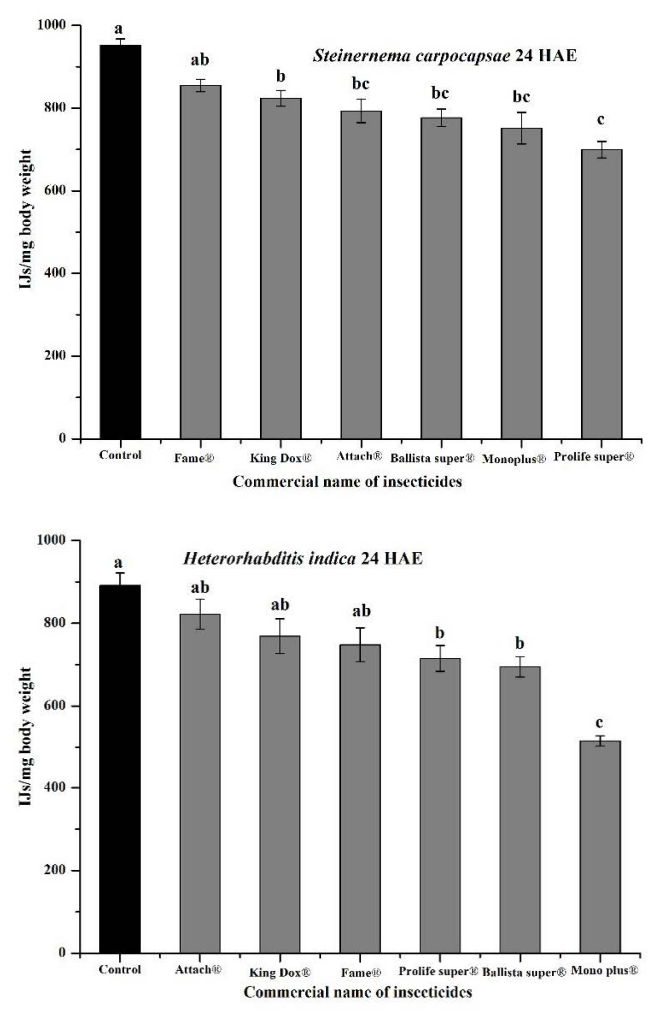

available to farmers when pests approach the economic threshold level. Commercial formulations of Fame ${ }^{\circledR}$, KingDox $^{\circledR}$ and Ballista Super ${ }^{\circledR}$ showed no adverse effects on the survival and infectivity of both nematodes species, whereas the IJs exposed to Proclaim ${ }^{\circledR}$ recorded $75.70 \%$ and $82.71 \%$ survival in $S$. carpocapsae and $H$. indica, respectively at 48 $\mathrm{h}$ of exposure, and it had adversely affected the infectivity of Galleria larvae. The present findings are in line with those of Yan et al. (2012) who opined that the viability of $S$. carpocapsae IJs were not affected by Proclaim ${ }^{\circledR}$, but their infectivity was impaired.

According to Fetoh et al. (2009) emamectin benzoate had no adverse effects on $S$. carpocapsae and a mixture of $S$. carpocapsae with formulated emamectin benzoate significantly increased mortality to greasy cutworm (Agrotis ipsilon), compared to $S$. carpocapsae alone. In our study, however, viability of $S$. carpocapsae and $H$. indica was not affected by Proclaim ${ }^{\circledR}$ (Emamectin benzoate), but their infectivity was zero in both the species of EPNs. Therefore, generalisations on EPNs tolerance to insecticides were inaccurate, because different findings among studies may be related to differences in chemical composition and formulation of the product (Koppenhofer and Grewal, 2005; Negrisoli Jr et al., 2010). Therefore, studies of the interac-
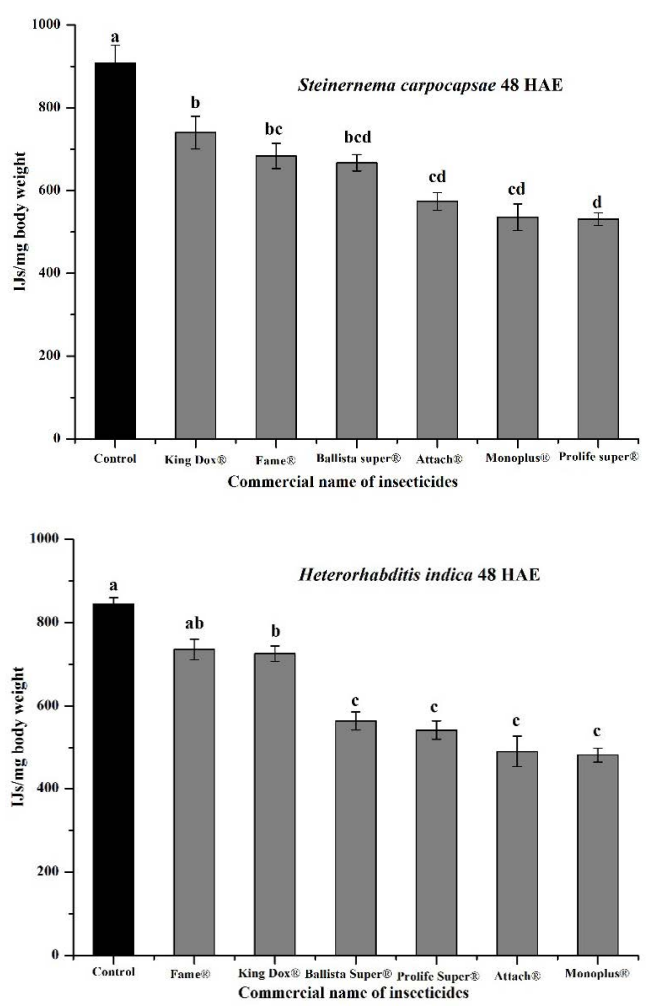

Fig. 2. The progeny production (Mean \pm SE) capacity of Steinernema carpocapsae and Heterorhabditis indica, in Galleria mellonella larvae at 24 and 48 hours after exposure in Helicoverpa armigera registered insecticides. Different letters on the top of error bars indicates statistically different values for different insecticide a.i./ha recommended for aerial application at $(P<0.05)$ using Tukey's test. Error bars indicate standard error $(n=5)$. 
tion and compatibility between insecticides and EPNs are recommended before field applications in IPM programs.

Among the organophosphate group (OP) of insecticides, when IJs were exposed to Attach $^{\circledR}$ and Monoplus ${ }^{\circledR}$ we could notice, lower survivability. Similarly, Zimmerman and Cranshaw (1990) also showed significant reduction of $S$. feltiae survival when exposed to OP compounds. Hence inhibition of acetylcholine esterase activity may be slightly toxic to both EPN strains. After exposure of IJs to these OP compounds, we also recorded moderate IJs infection of Galleria larvae and reduced reproduction rate. However, Rovesti and Deseo, 1990 reported that nematode reproduction in Galleria larvae under in vitro conditions was not affected by exposure to OP compounds and carbamates.

In the present study, IJs exposure to pyrethroid group of insecticide Ballista super ${ }^{\circledR}$ resulted in $73.6 \%$ and $84.0 \%$ survival of $S$. carpocapsae and $H$. indica, respectively, and also showed moderate effect on infectivity and reproduction rate. However, Negrisoli Jr et al. (2010) observed 88\% survival in $S$. carpocapsae when exposed to Cypermethrin. Negrisoli Jr. et al. (2008) reported that, pyrethroids registered higher mortality of $S$. carpocapsae (28.4\%) compared to H. bacteriophora (5.6\%) when exposed to Decis, similarly in our studies, $H$. indica showed higher survival as compared to $S$. carpocapsae. These results indicated that, insecticide tolerance also depends on the EPN species.

The present studies show that $S$. carpocapsae and $H$. indica can be successfully included in IPM of $H$. armigera. It may reduce the dependence on chemical insecticides and thus contribute to slowing down the development of insecticide resistance and preventing adverse effects on public health and the environment. The results of this work expand our knowledge on compatibility of EPN with registered insecticides for the control of $H$. armigera. Knowledge of the potential reproduction losses attributable to the used insecticides will be help to predict the required application rate of nematodes in IPM programs against $H$. armigera.

\section{ACKNOWLEDGEMENTS}

The authors thank the Director, National Bureau of Agricultural Insect Resources Bengaluru for providing the research facilities, the Indian Council of Agricultural Research New Delhi for financial support and the Director, Indian Institute of Pulses Research for deputing Mr. Devindrappa to NBAIR, Bengaluru for professional attachment training.

\section{REFERENCES}

Alves SB, Moino A, Almeida JEM. 1998. Produtos fitossanita rios e entomopato genos. In: Alves SB. (Ed.) Controle microbiano de insetos. FEALQ, Piracicaba. pp. 217-238.

Cabanillas HE, Poinar GO, Raulston JR. 1994. Steinernema riobravis (Rhabditida: Steinernematidae) sp. from Texas. Fund Appl Nematol. 17: 123-131.

Dent D. 2000. Cultural and interference methods. In: Dent D. (Eds.). Insect Pest Management 2nd edition. CABI publishing, Cambridge, MA. Pp. 235-266. Crossref PMid:10761764

Fitt GP. 1989. The ecology of Heliothis in relation to agro ecosystems. Annu Rev Entomol. 34: 17-52. Crossref

Fetoh BES, Khaled AS, El-Nagar TFK. 2009. Combined effect of entomopathogenic nematodes and biopesticides to control the greasy cut worm, Agrotis ipsilon (Hufn.) in the strawberry fields. Egypt Acad J Bio Sci. 2(1): 227-236.

Gowda CLL. 2005. Helicoverpa - The global problem. In: Sharma HC. (Ed.) Heliothis/Helicoverpa management: Emerging trends and Strategies for future research. Oxford and IBH Publishing, New Delhi. pp. 1-7. PMid: 15860376

Glazer I, Navon A. 1990. Activity and persistence of entomoparasitic nematodes tested against Heliothis armigera (Lepidoptera: Noctuidae). J Econ Entomol. 83(5): 1795-1800. Crossref

Hussain MA, Ahmad R, Ahmad W. 2014. Evaluation of Steinernema masoodi (Rhabditida: Steinernematidae) against soil dwelling life stage of Helicoverpa armigera (Lepidoptera: Noctuidae) in laboratory and micro plot study. Can J Plant Prot. 2(1): 4-8.

ICRISAT (International Crops Research Institute for the Semi-Arid Tropics). 1992. The Mid Term Plan. International Crops Research Institute for the SemiArid Tropics, Patancheru, Andhra Pradesh, India.

Kallia V, Sharma G, David I, Shapiro-Ilan DI, Ganguly S. 2014. Bio control potential of Steinernema thermophilum and its symbiont Xenorhabdus indica against Lepidopteran pests: virulence to egg and larval stages. J Nematol. 46(1): 18-26. 
Kaya HK, Stock SP. 1997. Techniques in insect Nematology. In: Lacey LA. (Ed.) Manual of techniques in insect pathology. Academic Press, San Diego, California. pp. 281-324. Crossref

Koppenhofer AM, Grewal PS. 2005. Compatibility and interactions with agrochemicals and other bio control agents. In: Grewal PS, Ehlers R, Shapiro-Ilan DI. (Eds.). Nematodes as Biocontrol Agents. CABI Publishing, Wallingford, Oxfordshire, UK. pp. 363381. Crossref

Nabil El-Wakeil, Nawal Gaafar, Ahmed Sallam,Christa Volkmar. 2013. Side effects of insecticides on natural enemies and possibility of their integration in plant protection strategies. In: Trdan S (Ed.). Insecticides development of safer and more effective technologies. Intech, Croatia. pp. 1-56. Crossref

Naser EK, Ali G, Hooshang RD, Davoud M, Samad A, Mansour O, Mohammad RM, Akbar S. 2012. A laboratory study of susceptibility of Helicoverpa armigera (Hubner) to three species of Entomopathogenic nematodes. Munis Ent Zool. 7(1): 372-379.

Negrisoli AS Jr, Barbosa CRC, Moino A Jr. 2008. Comparacao entre metodologias de avaliacao da compatibilidade de produtos fitossanita rios com nematoides entomopatogenicos (Nematoda: Rhabditida). Nematol Bras. 32(1): 65-75.

Negrisoli AS Jr, Garcia MS, Barbosa-Negrisoli CRC. 2010. Compatibility of entomopathogenic nematodes (Nematoda: Rhabditida) with registered insecticides for Spodoptera frugiperda (Smith, 1979) (Lepidoptera: Noctuidae) under laboratory conditions. Crop Prot. 29(6): 545-549. Crossref

Pawar CS, Bhatnagar VS, Jadhav DR. 1986. Heliothis species and their natural enemies, with their potential for biological control. Proc Indian Acad Sci. (Anim Sci). 95(6): 695-703. Crossref
Peters A, Poullot D. 2004. Side effects of surfactants and pesticides on Entomopathogenic nematodes assessed using advanced IOBC guidelines. IOBC/WPRS Bulletin. 27(6): 67-72.

Reed W, Pawar CS. 1982. Heliothis: a global problem. In: Reed W, Kumble V. (Eds.). Proceedings of the international workshop on Heliothis management. November 15-20, 1981, ICRISAT, Patancheru, India. pp. 9-14. PMid:6804661

Rovesti L, Deseo KV. 1990. Compatibility of pesticides with the Entomopathogenic nematodes, Steinernema carpocapsae Weiser and Steinernema feltiae Filipjev (Nematoda: Steinernematidae). Nematologica 36: 237-245. Crossref

Sharma HC. 2005. Heliothis/ Helicoverpa management: Emerging trends and strategies for future research. Oxford and Science publishers, USA. 469 pp.

SAS Institute: SAS version 9.3 System options. 2nd Edn. 2011. Cary, NC, USA, SAS Institute, USA.

Yan X, Moens M, Han R, Chen S, Clercq PD. 2012. Effects of selected insecticides on osmotically treated entomopathogenic nematodes. J Plant Dis Prot. 119(4): 152-158. Crossref

Zalucki MP, Dalglish G, Firempong S, Twine P. 1986. The biology and ecology of Heliothis armigera (Hübner) and Heliothis punctigera Wallengren (Lepidoptera: Noctuidae) in Australia: what do we know? Aust $J$ Zool. 34(6): 779-814. Crossref

Zimmerman RJ, Cranshaw WS. 1990. Compatibility of three entomopathogenous nematodes (Rhabditida) in aqueous solutions of pesticides used in turf grass maintenance. J Econ Entomol. 83: 97-100. Crossref 